\title{
LACTACIDEMIA DURING TRACK DAY MOTORCYCLE RACING COMPETITIONS
}

\author{
Marcelo CONTE ${ }^{1,2,3}$, João Vitor de SOUZA ANDRADE ${ }^{1}$, Gustavo AZEVEDO ${ }^{1}$, \\ Victor Augusto RAMOS FERNANDES ${ }^{1,4,5}$ \\ ${ }^{1}$ Group of Studies in Motor Sports and Physical Performance - School of Physical Education of \\ Jundiaí, São Paulo, Brazil \\ ${ }^{2}$ Conte Fit Sports Science, Brazil \\ ${ }^{3}$ Federal University of São Paulo, Brazil \\ ${ }^{4}$ Jundiaí Medical School, São Paulo, Brazil \\ ${ }^{5}$ Nossa Senhora do Patrocínio University - Cruzeiro do Sul University, Itu, São Paulo, Brazil \\ Corresponding author: \\ Victor Augusto RAMOS FERNANDES, Ph.D. \\ Group of Studies in Motor Sports and Physical Performance - School of Physical Education of \\ Jundiaí, Rua Dr. Rodrigo Soares de Oliveira $\mathrm{s} / \mathrm{n}^{\circ}$ \\ Anhangabaú - Jundiaí, São Paulo, Brazil \\ Phone: +55 11 4805-7955 \\ e-mail: dr.victoraugustofernandes@gmail.com
}

\begin{abstract}
Introduction: Motorbike racing is one of the most dangerous sports due to high speeds, and it is highly demanding on racers both mentally and physically. Objective: To verify the lactacidemia in motorbike racers before and after the Track Day race. Method: Nine non-professional male riders $(33 \pm 10.39$ years) who practiced Track Day race were studied. Plasma lactate was obtained twice: 30 minutes before and 5 minutes immediately after the Track Day race. Results: There was a significant increase in lactacidemia (87.5\%) after the 30-minute race (3.77 \pm 1.38 vs. $7.07 \pm$ $1.85 \mathrm{mmol})$. Conclusion: Lactacidemia in amateur motorbike racers increased significantly after the Track Day race. These data reinforce the results of other studies, which consider motorcycling as a sport high in terms of anaerobic metabolism. Thus, physical trainers and motorcycle racers should adopt strategies to stimulate this metabolic pathway in specific training.
\end{abstract}

Keywords: motorcycle, lactate, anaerobic threshold, exercise. 
Marcelo CONTE, João Vitor de SOUZAANDRADE, Gustavo AZEVEDO, Victor Augusto RAMOS FERNANDES: LACTACIDEMIADURING ..., 17-27

\section{LAKTACIDEMIJA NA MOTOCIKLISTIČNI DIRKI NA ODPRT DIRKAŠKI DAN}

\section{IZVLE $\breve{C E K}$}

Uvod: Motociklistične dirke so zaradi visokih hitrosti ena od najnevarnejših športnih disciplin, za tekmovalce pa so tudi fizično in psihično zelo obremenjujoče. Cilj: Preveriti raven laktacidemije pri udeležencih motociklistične dirke na odprt dirkaški dan (t. i. ,track day') pred tekmovanjem in po njem. Metoda: Preučevali smo devet nepoklicnih dirkačev (starih $33 \pm 10.39$ let), ki so se udeležili motociklističnega tekmovanja na dirkališču. Plazemski laktat smo jim odvzeli dvakrat: 30 minut pred dirko in 5 minut po njej. Rezultati: Zabeležili smo znatno povečanje laktacidemije (87.5\%) po 30-minutni dirki (3,77 \pm 1,38 mmol oz. 7,07 $\pm 1,85$ mmol). Zaključek: Laktacidemija pri amaterskih motociklističnih dirkačih je po tekmi na dirkališču močno narasla. Ti podatki potrjujejo rezultate drugih študij, ki motociklizem uvrščajo med športe z visokim deležem anaerobnega metabolizma. Trenerji in motociklistični dirkači bi tako morali izdelati strategije za spodbujanje te metabolične poti z namensko zasnovanimi treningi.

Ključne besede: motocikli, laktat, anaerobni prag, trening. 
Marcelo CONTE, João Vitor de SOUZAANDRADE, Gustavo AZEVEDO, Victor Augusto RAMOS FERNANDES: LACTACIDEMIA DURING ..., 17-27

\section{INTRODUCTION}

Motorcycling, also known as motorbiking, is a very popular sport worldwide. Intrinsic factors of the category, such as the high speeds of motorcycles, the imminent risk of fatal accidents, and a very high level of competitiveness among riders, characterize the sport as imposing great physical and psychological demands on the participants. The verification of the physical and psychological conditions of practitioners of this modality is made necessary as a result of the understanding established in the prescription of training that can mitigate the risk of accidents and improve the performance of this population (D'Artibale, Laursen \& Cronin, 2018). In this sense, the use of easily obtained markers, such as glucose, lactacidemia, heart rate, and temperature can help the trainers adapt the training cycles to the needs of each athlete (Potkanowicz \& Mendel, 2013; Conte, 2018; Barthel et al., 2020).

Lactacidemia (concentration of lactate in the bloodstream) is one of the most commonly used parameters to quantify physical effort and the predominant metabolism characteristic for energy supply during exercise (Manchado, Gobatto, Contarteza, Papoti, \& Mello, 2006). Lactate is a metabolite, a final product of anaerobic metabolism that results from glycolysis. The lactate production/clearance ratio is directly related to the type and intensity of physical exercise. Associated with this, lactate is part of a series of physiological mechanisms that protect the intracellular environment against changes in $\mathrm{pH}$ and consequently fatigue (Cathcart et al., 2008).

The method of measuring lactate concentration after sports car races has been used to compare the physiological responses between professional and amateur drivers, identifying direct relationships between competitiveness and the physical condition of the practitioner, which reinforces the need for specific training for that population (Barthel et al., 2020).

D’Artibale, Tessitore, Tiberi, Capranica (2007), investigated 26 female drivers during free practice, qualifying sessions, and official races and observed a significant increase in lactacidemia $2.2 \pm 0.5 \mathrm{mmol} / \mathrm{l}$ vs. $4.8 \pm 2.6 \mathrm{mmol} / \mathrm{l}$, regardless of the competition phase. On the other hand, Sperlich, Osman-Reinkens, Zinner, Krueger, and Holmberg (2014) followed 10 kart drivers and observed a significant increase in lactate concentrations immediately after the 30-minute race. However, the physiological changes occurring during the practice of motorsports are still little known, especially in motorcycling. Studies to observe changes in lactacidemia in motorbike racers with the aim to improve the training strategies of the respective sport are required. Thus, the objective of the present study is to verify the lactacidemia of riders before and after a motorbike race. 
Marcelo CONTE, João Vitor de SOUZA ANDRADE, Gustavo AZEVEDO, Victor Augusto RAMOS FERNANDES: LACTACIDEMIA DURING ..., 17-27

\section{MATERIAL AND METHOD}

\section{Sample characteristics}

The nine amateur motorbike racers participating in this study and constituting a sample for accessibility, with an average age of $33+10.4$ years, were participants of the Track Day race, an event open to professional racers and/or amateurs and held in a professional race track. Five of the riders (aged $25.8+7.88$ years) participated in the race with current "speed" motorcycles, namely, Kawasaki ninja 250cc, Kawasaki zx6 600 (manufactured between 2000 and 2009), Suzuki GSX-R750 (manufactured between 2000 and 2008), while the remaining four riders (aged $42+3.2$ years) with classic motorcycles (all Thruxton 900cc manufactured in the year 1965). The research followed the ethical recommendations, obtaining the Free and Informed Consent Forms signed by the volunteers and the approval of the Ethics Committee of the Escola Superior de Educação Física de Jundiaí (Protocol Number: 2,848,416). The starting grid of the race was composed of 22 drivers; our sample was 9 drivers. In this sense, adopting a $95 \%$ confidence level, we obtain a $25.7 \%$ confidence interval for the sample of this study.

\section{Inclusion criteria}

Motorbike riders participating in the Track Day race. Male. Age over 18 years. Signature of the Free and Informed Consent Form (ICF). Exclusion criteria: presence of any injury limiting the performance of movements during the tests; refusal of consent to participate in the research.

\section{Experimental Procedures}

Plasma lactate was obtained on two occasions: A) 30 minutes before and B) 5 minutes after the Motorbike Track Day race, which consisted of 30 minutes of racing at the Haras Tuiuti Circuit, a 2,000-meter paved track circuit (Figure 1). Blood was collected from the digital pulp, using disposable lancets (Accu-Chek Softclix ${ }^{\circledR}$ Pro); a drop of blood was applied to a specific area of the BM-lactate reactive strip and the samples were measured on the Accutrend $\AA$ Lactate Lactometer. 
Marcelo CONTE, João Vitor de SOUZAANDRADE, Gustavo AZEVEDO, Victor Augusto RAMOS FERNANDES: LACTACIDEMIA DURING ..., 17-27

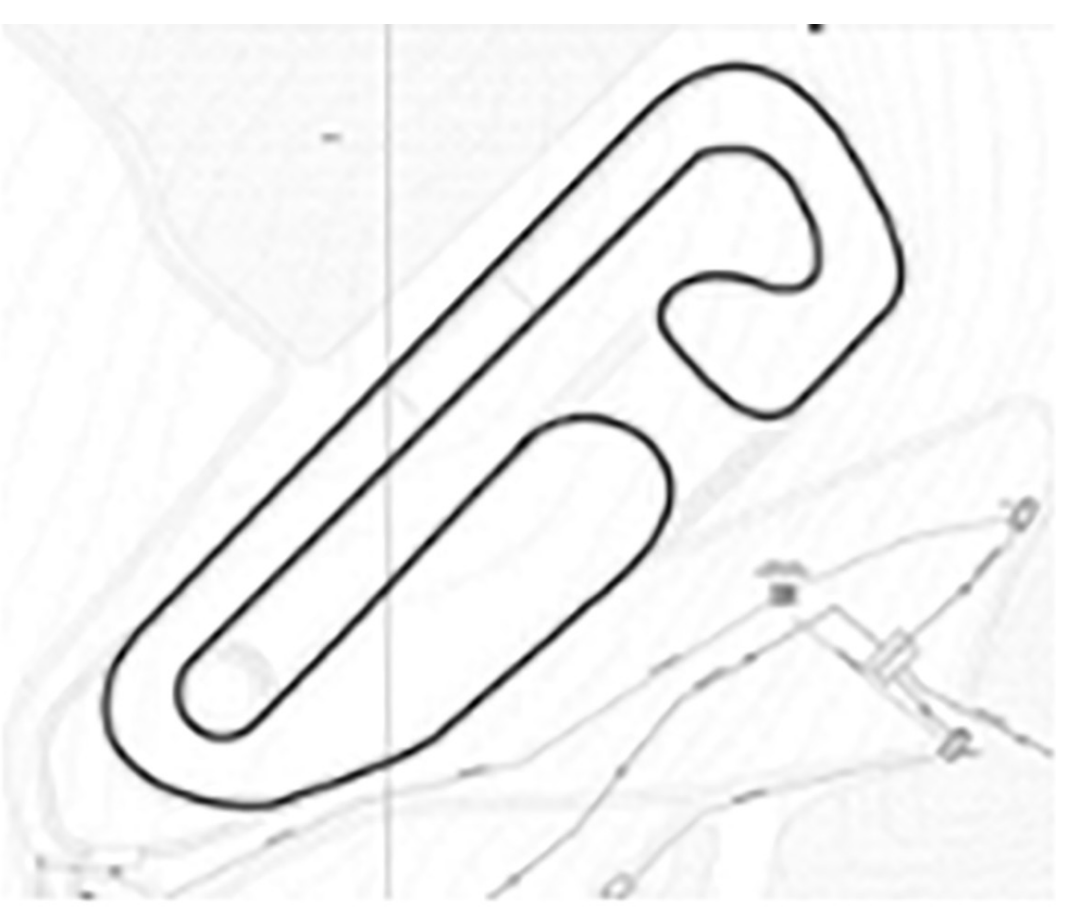

Figure 1: Main Circuit - Haras Tuiuti

\section{Data analysis}

For comparison between moments, a Student's t-test paired with variables with normal distribution was used, with a Bonferroni's post-test, adopting a 5\% significance level, for all analyses.

\section{RESULTS}

Results are shown in Table 1 and Graphs 1 to 3. You can see that there was a significant increase in the lactacidemia of the motorcyclists, in the age and categories, after the Track Day races. 
Marcelo CONTE, João Vitor de SOUZAANDRADE, Gustavo AZEVEDO, Victor Augusto RAMOS FERNANDES: LACTACIDEMIADURING ..., 17-27

Table 1: Comparison of the mean and standard deviation of lactacidemia before and after racing between riders of vintage and current motorcycles.

\begin{tabular}{|l|c|c|}
\hline \multirow{2}{*}{ Category } & \multicolumn{2}{|c|}{ Time } \\
\cline { 2 - 3 } & before $(\mathbf{m m o l} / \mathbf{l})$ & after $(\mathbf{m m o l} / \mathbf{l})$ \\
\hline Current bikes & $3.36+0.67$ & $6.06+1.95^{*}$ \\
\hline Vintage bikes & $4.30+1.95$ & $7.67+1.78^{*}$ \\
\hline \multicolumn{1}{|c|}{ Total } & $3.77+1.38$ & $7.07+1.85^{*}$ \\
\hline
\end{tabular}

$* \mathrm{p}<0,05$

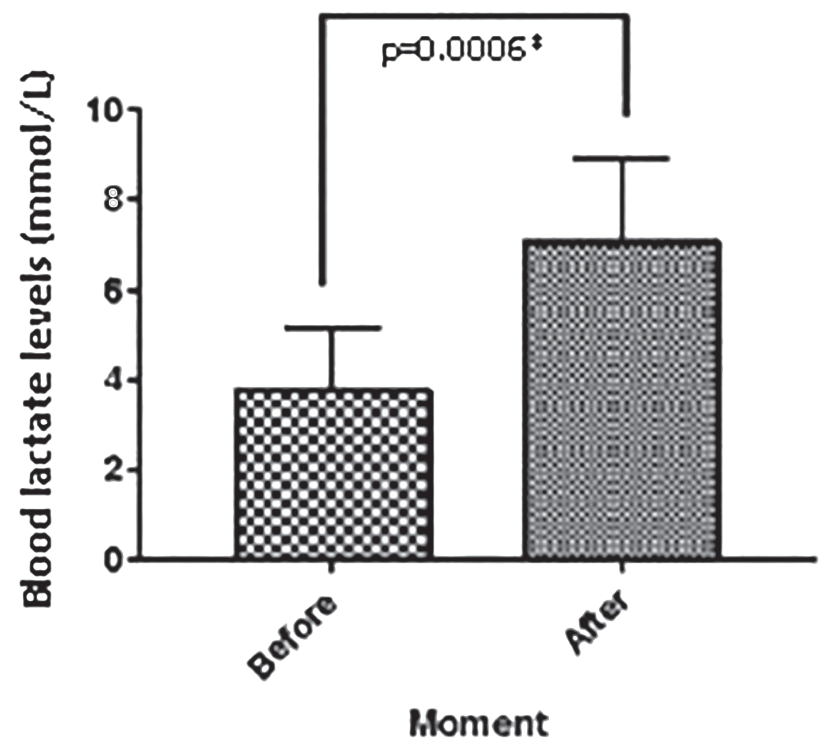

Graph 1: Comparison of blood lactate levels before and after motorcycle racing.

The significant increase in lactate concentrations after Track Day suggests that motorbiking is a sport of high anaerobic demand (Graph 1).

Descriptively, it is observed that the blood lactate concentration of vintage motorcycle riders, both before and after the race, was higher than that of the newer motorcycle riders (Graph 2).

It can be seen that there was a statistically significant difference concerning the average age of the motorbike racers $(p=0.0066)$. The riders of the newer motorcycles were younger than those of the vintage ones (Graph 3). 
Marcelo CONTE, João Vitor de SOUZAANDRADE, Gustavo AZEVEDO, Victor Augusto RAMOS FERNANDES: LACTACIDEMIA DURING ..., 17-27

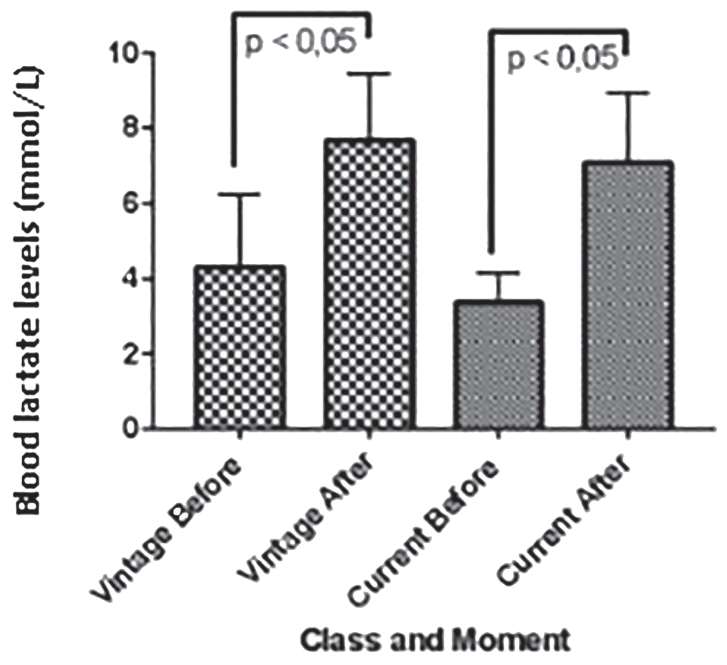

Graph 2: Comparison of blood lactate levels before and after racing with vintage and current motorcycles.

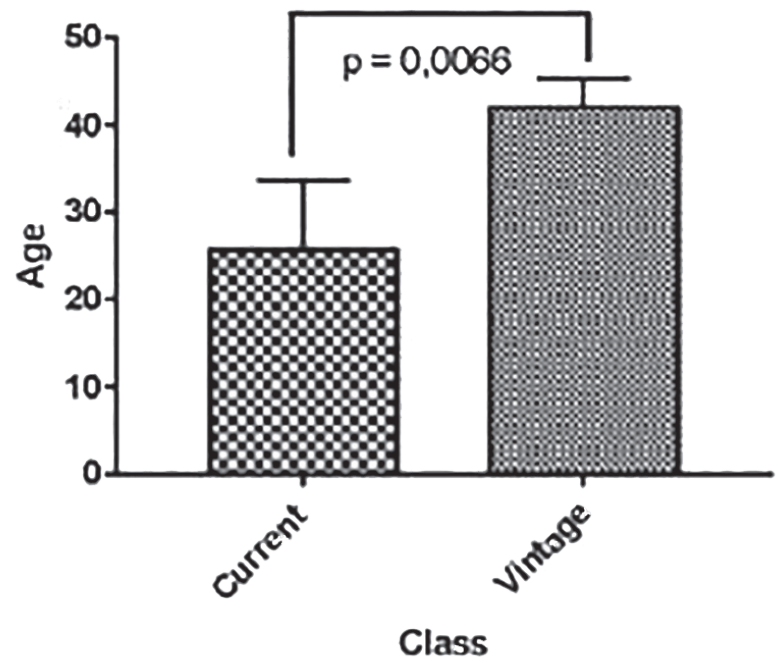

Graph 3: Comparison of motorbike racers'age (average) in relation to the categories evaluated. 


\section{DISCUSSION}

We observed in the present study that the motorcycle racers' lactacidemia increased significantly $(87.77 \%)$ after the Track Day race. At the same time, in different categories of motor sports, there is an increase in lactate concentrations after competitions and/or training. We can cite as an example, the studies of Del Rosso, Abreu, Webb, Zouhal, \& Boullosa (2016), reporting an increase of 395\% in rally drivers; a case study of Gobatto, Mendonça, \& Matsushigue (2000), with 950\% in kart, and 53\% in F-Corsa racers, as well as Simões, Crisp, Verlengia, \& Pellegrinotti (2016) with a 209\% increase in motocross riders.

In the present study, a significant increase in lactacidemia was also observed right after the race on the Track Day, average of $7.07 \pm 1.87 \mathrm{mmol} / \mathrm{l}$, similar to the average found by D'Artibale et al. (2018) in a study with 34 riders of the European Motorbike Championship categories $125 \mathrm{GP}, 250 \mathrm{GP}$ and $600 \mathrm{ccs}$, where the lactate concentrations after the respective runs were $6.0 \pm 2.1 \mathrm{mmol} / \mathrm{l}$. And similar to Filaire, Filaire, \& Le Scanff (2007), that observed a significant increase in lactacidemia after the motorbike race $(5.6 \pm 2.1 \mathrm{mmol} / \mathrm{l})$; on the other hand, Gobbi, Francisco, Tuy, and Kvitne (2005) observed that Motocross riders recorded lactacidemia of $5.3 \pm 2.1 \mathrm{mmol}$ at the end of the race. However, in racing drivers, Schwaberger (1987) also observed a significant increase in lactacidemia after racing and pointed out that lactate is an important metabolic marker of physical stress.

It is suggested that motorcycle racers have a high demand for static muscle contraction, this means that the muscles, mainly in the abdominopelvic region, lower limbs and forearms of the riders, presented important isometric activation as well as possible reduction of peripheral blood flow during riding, conditions that exacerbate the requirement for lactic anaerobic metabolism.

Both current and vintage motorcycle racers showed an increase in lactacidemia, although descriptively vintage motorcycle racers showed higher lactate concentrations, both at rest and after the race. Two factors may have influenced this result, the age group (riders in the vintage motorcycle class had a significantly higher average age) and the characteristics of the motorcycles.

We recognize that several factors can influence lactacidemia, such as the characteristics of the circuit, power and characteristics of the racing motorcycle, physical fitness of the motorcycle racers. However, data from the present study indicate that even amateurs racing on unofficial motorcycles, in events such as Track Day, are subjected to a high-performance and physically demanding practice, suggesting the need for special attention regarding physical preparation.

Again, all drivers showed an increase in lactate concentrations after the race. Febbraio et al. (1994) show that during extreme exercise, the individual's temperature causes changes in lactate concentration; the higher the body temperature, the greater the use of muscle glycogen, increasing lactate levels, which may be one of the reasons for increased lactacidemia after the race. In this sense, the driver's clothing and the high temperature on the track $\left(36^{\circ} \mathrm{C}\right)$ on the day of the race, associated with high emotional 
Marcelo CONTE, João Vitor de SOUZAANDRADE, Gustavo AZEVEDO, Victor Augusto RAMOS FERNANDES: LACTACIDEMIA DURING ..., 17-27

stress and the great muscular demand, both dynamic and static, for riding (Potkanowicz \& Mendel, 2013) can explain the elevation of lactate, which is considered an important marker of exercise intensity (Goodwin, Harris, Hernández, \& Gladden, 2007).

The progressive increase in the intensity of effort promotes the recruitment of motor units of the FR (Fatigue Resistance) type and later on those of the FF (Fast Fatigue) type. Therefore, the production of lactate by muscle fibers increases in the same order as the recruitment pattern. Regardless of the type of contraction, muscle fibers of type IIA and IIB are recruited in high-intensity exercises, these same fibers being the most likely to produce lactate. However, although the increase in lactacidemia is an indicator of increased intensity of effort, protective effects of lactate exposure or acidosis induced in muscle contractions with potassium depression in isolated rodent muscles are reported. Besides, exposure to sodium lactate can alleviate severe muscle fatigue, and sodium lactate intake can increase exhaustion time during running in humans. Together, these latest findings led to the idea that lactate $/ \mathrm{H}+$ may have an ergogenic effect during exercise (Cairns, 2006).

\section{CONCLUSION}

The present study found that lactacidemia increased significantly after the Track Day race in amateur motorbike racers. These data reinforce the results of other studies, which consider motorcycling as a sport with elevated anaerobic metabolism. Thus, physical trainers and motorcycle racers should adopt strategies to stimulate this metabolic pathway in specific training.

\section{Study limitations}

Classificatory training and free training performed during the day of the competition, as well as physical activities that may have been performed during the 48 hours before data collection, may have influenced the lactacidemia values. On the other hand, it was not possible to evaluate and know the drivers' IAT, for a possible comparison between the lactate concentration obtained in the anaerobic threshold and the lactacidemia after the race.

\section{REFERENCES}

Barthel, S. C., Buckingham, T. M., Haft, C. E., Bechtolsheimer, J. E., Bechtolsheimer, T. A., \& Ferguson, D. P. (2020). A comparison of the physiological responses in professional and amateur sports car racing drivers. Research Quarterly for Exercise and Sport. In print. https://doi.org/10.1080/02701367.2019.1690120. 
Marcelo CONTE, João Vitor de SOUZAANDRADE, Gustavo AZEVEDO, Victor Augusto RAMOS FERNANDES: LACTACIDEMIADURING ..., 17-27

Cairns, S. P. (2006). Lactic acid and exercise performance. Culprit or friend? Sports Medicine 36(4), 279-291. https://doi.org/10.2165/00007256-200636040-00001.

Cathcart, A. J., Turner, A. P., Butterworth, C., Parker, M., Wilson, J., \& Ward, S. A. (2008). Ventilatory control during intermittent high-intensity exercise in humans. In: M. J. Poulin, R. J. A. Wilson (eds), Integration in Respiratory Control. Advances in Experimental Medicine and Biology, vol. 605. New York, NY: Springer. https://doi. org/10.1007/978-0-387-73693-8_35.

Conte, M. (2018). Respostas fisiológicas e bioquímicas frente à prova de rali de regularidade. Revista Pulsar, 10(2), 40-47.

D'Artibale, E., Laursen, P. B., Cronin, J. B., (2018). Human performance in motorcycle road racing: a review of the literature. Sports Medicine, 48, 1345-1356. https://doi. org/10.1007/s40279-018-0895-3.

D'Artibale, E., Tessitore, A., Tiberi, M., Capranica, L. (2007). Heart rate and blood lactate during official female motorcycling competitions. International Journal of Sports Medicine, 28(8), 662-666. https://doi.org/10.1055/s-2007-964889.

Del Rosso, S., Abreu, L., Webb, H. E., Zouhal, H. \& Boullosa, D. A. (2016). Stress markers during a rally car competition. Journal of Strength and Conditioning Research, 30(3), 605-614. https://doi.org/10.1519/JSC.0000000000001131.

Filaire, E., Filaire, M., \& Le Scanff, C. (2007). Salivary cortisol, heart rate and blood lactate during a qualifying trial and an official race in motorcycling competition. Journal of Sports Medicine and Physical Fitness. 47(4), 413-417.

Febbraio, M. A., Snow, R. J., Hargreaves, M., Stathis, C. G., Martin, I. K., \& Carey, M. F. (1994). Muscle metabolism during exercise and heat stress in trained men: effect of acclimation. Journal of Applied Physiology, 76(2), 589-597. https://doi.org/10.1152/ jappl.1994.76.2.589.

Gobatto, C. A., Mendonça, E. R., \& Matsushigue, K. A. (2000). Respostas do lactato sanguíneo e da frequência cardíaca em duas diferentes provas do automobilismo. Revista Brasileira de Medicina do Esporte, 6(1), 29-34. https://doi.org/10.1590/S151786922000000100007.

Gobbi, A. W., Francisco, R. A., Tuy, B., \& Kvitne, R. S. (2005) Physiological characteristics of top level off-road motorcyclists. British Journal of Sports Medicine, 39(12), 927-931. https://doi.org/10.1136/bjsm.2005.018291.

Goodwin, M. L., Harris, J. E., Hernández, A., \& Gladden, L. B. (2007). Blood lactate measurements and analysis during exercise: a guide for clinicians. Journal of Diabetes Science and Technology. 1(4), 558-569. https://doi.org/10.1177/193229680700100414

Manchado, F. B., Gobatto, C. A., Contarteza, R. V. L., Papoti, M. \& Mello, M. A. R. (2006). Máxima fase estável de lactato é ergômetro-dependente em modelo experimental utilizando ratos. Revista Brasileira de Medicina do Esporte. 12(5), 259-262. https:// doi.org/10.1590/S1517-86922006000500007.

Potkanowicz, E. S., \& Mendel, R. W. (2013). The case for driver science in motorsport: a review and recommendations. Sports Medicine, 43(7), 565-574. https://doi.org/10.1007/ s40279-013-0040-2.

Schwaberger, G. (1987). Heart rate, metabolic and hormonal responses to maximal psycho-emotional and physical stress in motor car racing drivers. International Archives of Occupational and Environmental Health, 59(6), 579-604. https://doi.org/10.1007/ BF00377921. 
Marcelo CONTE, João Vitor de SOUZAANDRADE, Gustavo AZEVEDO, Victor Augusto RAMOS FERNANDES: LACTACIDEMIA DURING ..., 17-27

Simões, V. R., Crisp, A. H., Verlengia, R., \& Pellegrinotti, I. L. (2016). Neuromuscular and Blood Lactate Response After a Motocross Training Session in Amateur Riders. Asian Journal of Sports Medicine, 7(2), e23805. https://doi.org/10.5812/asjsm.23805.

Sperlich, B., Osman-Reinkens, S., Zinner, C., Krueger, M., \& Holmberg, H. C. (2014). Cardiorespiratory, metabolic and hormonal responses during open-wheel indoor kart racing. Journal of Sports Medicine and Physical Fitness. 54(4), 475-480. Retrieved from: https://www.minervamedica.it/en/journals/sports-med-physical-fitness/article. php?cod=R40Y2014N04A0475. 